\title{
ANTIBACTERIAL EFFECT OF FLAVONOIDS FROM PROPOLIS PRODUCED BY TRIGONA ON ATPASE ACTIVITY OF STREPTOCOCCUS MUTANS
}

\author{
DIAN ERLIANDA, MOCHAMAD FAHLEVI RIZAL*, SARWORINI B BUDIARDJO
}

Department of Pediatric Dentistry, Faculty of Dentistry, Universitas Indonesia, Jakarta, Indonesia. Email: levipedo@gmail.com

Received: 16 September 2017, Received and Accepted: 07 November 2017

ABSTRACT

Objective: Caries are a major problem related to oral health among children. As it is an infectious disease, bacteria, especially Streptococcus mutans, play an important role in caries. Flavonoids have been known to have antibacterial effects, and ethanol, even at very low concentrations, reportedly has antibacterial effects and is widely used as a basic ingredient in drugs.

Aim: This study aims to analyze the antibacterial effects of different concentrations of propolis flavonoids and ethanol against $S$. mutans ATPase activity.

Methods: $S$. mutans cells were exposed to $0.5 \%, 0.25 \%, 0.1 \%, 0.075 \%$, and $0.05 \%$ propolis flavonoids and then incubated in an anaerobic atmosphere for $48 \mathrm{~h}$. The ATPase activity in these cells was then tested using a colorimetric assay.

Results: No significant difference was found in the average ATPase activity of $S$. mutans after treatment with various concentrations of propolis flavonoids and ethanol.

Conclusions: Thus, $0.5 \%, 0.25 \%, 0.1 \%, 0.075 \%$, and $0.05 \%$ propolis flavonoids and $10 \%$ ethanol had similar effects against $S$. mutans ATPase activity. Further studies are necessary to evaluate the efficacy of flavonoids from Trigona spp. propolis.

Keywords: flavonoids, propolis, antibacterial, ATPase activity, Streptococcus mutans.

(C) 2017 The Authors. Published by Innovare Academic Sciences Pvt Ltd. This is an open access article under the CC BY license (http://creativecommons. org/licenses/by/4. 0/) DOI: http://dx.doi.org/10.22159/ijap.2017.v9s2.02

\section{INTRODUCTION}

Dental caries are a significant oral health problem in children worldwide. In 2007, the World Health Organization showed that the rate of dental caries in children in developing countries is about 50-60\%. In the United States, over 50\% of children aged 5-9 years children have at least one cavity or restoration, and this rate increases to $78 \%$ among children aged 17 years. A similar situation has been found through a cross-sectional survey in China, 55\% of preschool children aged 3-5 years have dental caries. In Indonesia, the Ministry of Health revealed that $64.5 \%$ children aged $1-14$ years have dental cavities [1].

Caries are a pathological condition characterized by demineralization of inorganic parts of teeth and influenced by several factors such as diet, host response, presence of microorganisms, and time. Given that it an infectious condition, bacteria play an important role in the process of caries. Recent studies have suggested that streptococci may be significant in the development of this disease, and Streptococcus mutans, in particular, is considered a major causative agent of dental caries [2].

One of the most important characteristics underlying the virulence of $S$. mutans is its ability to produce glucosyltransferases, which are enzymes that synthesize intracellular polysaccharides and extracellular polysaccharides. Extracellular polysaccharides, especially water-insoluble glucans, mediate the adherence of $S$. mutans and other bacteria to the tooth surface, contributing to the formation of dental plaque biofilms. Characteristics equally important to the virulence and cariogenic properties of $S$. mutans are its acidogenicity and aciduricity, that is, its ability to generate acidic end-products and survive at low $\mathrm{pH}[3,4]$.

Tolerance to acidic environments and an adaptive response on exposure to low $\mathrm{pH}$ is important in the pathogenesis of dental caries. Unlike most oral microorganisms, $S$. mutans thrives under acidic conditions and become the dominant bacterium in cultures with reduced $\mathrm{pH}$ [3]. Earlier studies have found that the key factor contributing to the aciduric response of $S$. mutans is proton-translocating ATPase. This finding suggests that suppression of this virulence factor (ATPase) could be used to prevent dental caries [5]. The use of preventive treatment to reduce the incidence of caries has been examined, and additional antibiotics are occasionally needed to eliminate plaque bacteria. However, antibiotics often have undesirable effects. Antibacterial agents used in the prevention of caries, including chlorhexidine, amine fluorides, or products containing such agents, are reported to exhibit toxicity and cause staining, or in the case of ethanol (commonly found in mouthwash), have been linked to oral cancer [6,7]. Thus, interest in naturally derived biologically active compounds that may have potential therapeutic uses in medicine and dentistry has been increasing.

Propolis, a nontoxic resinous hive product collected by Trigona spp. from various plant resources, has been recognized to have several properties that benefit human health, including the ability to prevent oral disease. One of the most important chemical compounds in propolis is flavonoids, which also have many useful properties including antibacterial activity, anti-inflammatory activity, antioxidant activity, and antitumor activity [8]. Propolis is a suggested alternative to antibiotics, with antibacterial effects against a wide range of bacteria including Escherichia coli, Staphylococcus aureus, Staphylococcus epidermis, Enterococcus spp., and Bacillus cereus [9]. Studies have found that flavonoids can inhibit bacterial growth, but the mechanism of action of these substances against the virulence of $S$. mutans remains to be investigated [10].

In the present study, we analyzed ATPase activity to assess the antibacterial effects of different concentrations of flavonoids from propolis and compared them with ethanol as the gold standard antibacterial agent in inhibiting the activity of $S$. mutans. 


\section{MATERIALS AND METHODS}

\section{Ethical statement}

This study was approved by the Ethical Committee of the Faculty of Dentistry, Universitas Indonesia, Number: 111/Ethical Approval/ FKGUI/XII/2016; protocol number: 051081216.

\section{Sample of flavonoids from propolis}

Raw propolis from a Trigona spp. beehive was obtained from Luwu, North Sulawesi. Flavonoids were extracted from this propolis using the maceration method. $1 \mathrm{~kg}$ of propolis was placed in an electrical macerator, and $5 \mathrm{~L} \mathrm{95 \%} \mathrm{ethanol} \mathrm{was} \mathrm{added} \mathrm{as} \mathrm{a} \mathrm{solvent.} \mathrm{This} \mathrm{mixture}$ was macerated 12 times for $15 \mathrm{~min}$ each, with a grace period of $5 \mathrm{~min}$ between each stirring, immersed for $120 \mathrm{~h}$, and then filtered with a funnel and filter paper to separate the filtrate from the dregs. The ethanol content in the filtrate was allowed to evaporate on a porcelain plate, and a thick extract was obtained. This extract was placed in an Erlenmeyer tube; $500 \mathrm{~mL}$ of toluene solution was added and stirred until the extract dissolved. Then, $1.5 \mathrm{~L}$ of water:ethanol solution $(2: 1 \mathrm{v} / \mathrm{v}])$ was added and stirred until the mixture was homogenous, and it was then left for $24 \mathrm{~h}$. Subsequently, the solution was transferred to a separating funnel and allowed to form two layers. The bottom solution was separated and evaporated to obtain a viscous extract.

To achieve $0.5 \%, 0.25 \%, 0.1 \%, 0.075 \%$, and $0.05 \%$ concentrations of flavonoids from the propolis, the extract was diluted with Aquadest. For example, to obtain $0.5 \%$ flavonoids, $50 \mathrm{mg}$ of the extract was dissolved in sterile Aquadest to make the volume up to $10 \mathrm{~mL}$. Further, $10 \%$ ethanol was obtained by dissolving $10 \mathrm{~mL}$ of $100 \%$ ethanol in $90 \mathrm{~mL}$ Aquadest.

\section{Bacterial strain, culture, and identification}

The antibacterial activity of flavonoids of different concentrations was evaluated against $S$. mutans (ATCC31987) ATPase using a colorimetric assay. The bacterial strains were obtained from the Laboratory of Oral Biology, Indonesia University. S. mutans was activated in trypticase soy with sucrose and bacitracin (TYS20B) agar and incubated in an anaerobic atmosphere $\left(10 \% \mathrm{H}_{2}, 5 \% \mathrm{CO}_{2}\right.$, and $\left.85 \% \mathrm{~N}_{2}\right)$ at $37^{\circ} \mathrm{C}$ for $48 \mathrm{~h}$. Then, 3-5 colonies were collected, placed in TYS broth, and incubated in an anaerobic atmosphere at $37^{\circ} \mathrm{C}$ for $48 \mathrm{~h}$. The bacteria were then grown in TYS20B agar at $37^{\circ} \mathrm{C}$ in an anaerobic atmosphere for $48 \mathrm{~h}$. The $S$. mutans culture was identified using visual inspection and Gram staining.

\section{Exposure of bacterial cultures to flavonoids}

Twenty-two tubes containing $5 \mathrm{~mL}$ TYS broth were sterilized by autoclaving. Three colonies of $S$. mutans were then placed in each tube and stirred well, and $5 \mathrm{~mL}$ of propolis with different flavonoid concentrations was added. One tube of $10 \%$ ethanol with bacterial colonies used as the positive control, while one with only bacterial colonies was used as the negative control. All tubes were incubated for $48 \mathrm{~h}$ at $37^{\circ} \mathrm{C}$.

\section{ATPase activity assay}

ATPase activity was determined in permeabilized cells of S. mutans that was exposed to the propolis flavonoids at various concentrations. The bacterial samples were centrifuged (3500 rpm, $10 \mathrm{~min}, 4^{\circ} \mathrm{C}$ ), and the pellet cell was washed with $5 \mathrm{~mL}$ PBS and centrifuged again ( $3500 \mathrm{rpm}, 10 \mathrm{~min}, 4^{\circ} \mathrm{C}$ ), followed by a series of freezing and thawing. Samples were pretreated with buffer solution $(10 \mathrm{mM}$ Tris-HCl, $\mathrm{pH} 8.5$; $100 \mathrm{mM} \mathrm{NaCl} ; 0.25 \%$ Tween 20 ) and sonicated (3 cycles, 15 s working, $1 \mathrm{~min}$ free) on an ice bath to disrupt the cells. Next, the samples were centrifuged $\left(13000 \mathrm{rpm}, 10 \mathrm{~min}, 4^{\circ} \mathrm{C}\right)$, and the supernatant was collected in a separate tube. ATPase activity was measured using the colorimetric ATP hydrolysis assay based on the measurement of the free inorganic phosphate moiety released from ATP [11]. A $45 \mathrm{~mL}$ reaction mixture containing $0.5 \mathrm{~mL}$ of $0.1 \mathrm{M} \mathrm{MgCl}_{2} ; 5 \mathrm{~mL}$ of $1 \mathrm{mM}$ MOPS (buffer solution); $0.1 \mathrm{~mL}$ of $0.1 \mathrm{M} \mathrm{ATP}$; and $38.5 \mathrm{~mL} \mathrm{H}_{2} \mathrm{O}$ was added into the wells of a plate, and $5 \mathrm{~mL}$ of the bacterial samples was then added to the wells.
The plates were incubated at room temperature for $45 \mathrm{~min}$, and $100 \mathrm{~mL} /$ well of a dye solution (water, $0.081 \%$ malachite green, $5.7 \%$ ammonium molybdate, and 2.3\% polyvinyl alcohol, 2:2:1:1 [v/v]) was added to each well, shaken until homogenized, and incubated for $5 \mathrm{~min}$. Next, $25 \mathrm{~mL} /$ well of $30 \%$ sodium citrate was added, and the optical density was read using an ELISA reader at a wavelength of $590 \mathrm{~nm}$. In this experiment, the positive control was S. mutans with $10 \%$ ethanol and the negative control was $S$. mutans colonies without any test material. Color absorption was measured using a microplate reader $(590 \mathrm{~nm})$ with the negative control as the reference standard.

\section{Statistical analysis}

One-way ANOVA was used to determine differences in S. mutans ATPase activity after exposure to various concentrations of flavonoids from propolis and ethanol.

\section{RESULT}

The results of the influence of various concentrations of flavonoids from propolis and ethanol on $S$. mutans ATPase activity are shown in Table 1.

Statistically, no significant differences were found in the average ATPase activity of S. mutans (determined on the basis of optical density) after treatment with various concentrations of propolis flavonoids and ethanol. The lowest ATPase activity was found in the group treated with $0.5 \%$ propolis flavonoids, followed by $0.05 \%, 0.25 \%, 0.075 \%$, and $0.1 \%$. Low OD values indicate reduced ATPase activity.

Since significance ANOVA has shown 0.462 ( $p>0.05$ ), we concluded that there was no significant difference between the average value of $S$. mutans ATPase activity after treatment with various concentrations of flavonoids from propolis and ethanol.

\section{DISCUSSION}

The role of $S$. mutans in the pathogenesis of caries is well-documented. As mentioned above, this organism possesses several virulenceenhancing characteristics such as aciduricity, acidogenicity, and adherence. Therefore, suppressing the enzymes associated with these virulence mechanisms is an appealing approach for prevention of S. mutans persistence and consequently, dental caries.

The aim of the current investigation was to evaluate and compare the antibacterial effects of flavonoids from propolis and $10 \%$ ethanol on S. mutans activity by analyzing changes in the ATPase activity of the bacterium when subjected to these agents. ATPase activity changes were determined on the basis of optical density. ATPase is an important enzyme that plays key roles in cell metabolism, ion transport, intercellular protein activity, and regulation of internal $\mathrm{pH}$. Regulation of cytoplasmic $\mathrm{pH}$ levels is essential for bacterial survival [4].

Table 1: Comparison of mean values of $S$. mutans ATPase activity after treatment with various concentrations of propolis flavonoids and ethanol

\begin{tabular}{|c|c|c|c|}
\hline Antibacterial agents & $\mathbf{n}$ & $\begin{array}{l}\text { Mean value of ATPase } \\
\text { activity (optical density) } \pm \text { SD }\end{array}$ & $\mathbf{p}$ \\
\hline $10 \%$ Etanol & 4 & $0.31 \pm 0.195$ & 0.462 \\
\hline $\begin{array}{l}0.5 \% \text { propolis } \\
\text { flavonoid }\end{array}$ & 4 & $0.17 \pm 0.065$ & \\
\hline $\begin{array}{l}0.25 \% \text { propolis } \\
\text { flavonoid }\end{array}$ & 4 & $0.24 \pm 0.047$ & \\
\hline $\begin{array}{l}0.1 \% \text { propolis } \\
\text { flavonoid }\end{array}$ & 4 & $0.25 \pm 0.061$ & \\
\hline $\begin{array}{l}0.075 \% \text { propolis } \\
\text { flavonoid }\end{array}$ & 4 & $0.24 \pm 0.056$ & \\
\hline $\begin{array}{l}0.05 \% \text { propolis } \\
\text { flavonoid }\end{array}$ & 4 & $0.21 \pm 0.035$ & \\
\hline
\end{tabular}


ATPase is involved in ATP synthesis through enzyme rotation (rotary proton force). The rotation of the enzyme is influenced by the $\mathrm{pH}$ of the environment, production, and consumption of internal protons as well as the transfer of acid through the cell membrane. The membranebound ATPase $\left[\mathrm{F}_{0} \mathrm{~F}_{1}\right.$-ATPase $]$ system pumps protons while maintaining the internal $\mathrm{pH}$ value. Ions move from high to low concentration. In acidic conditions, $\mathrm{H}^{+}$is present in abundance and causes ATPase in the cell membrane to rotate faster and produce more ATP. Thus, bacteria gain energy to survive, and this also mediates the process of demineralization. It has been demonstrated that increased ATPase activity is correlated with increased transcription of the ATPase operon in $S$. mutans, which can be regulated at the transcriptional level in response to growth $\mathrm{pH}$. This is considered the primary determinant of acid tolerance in S. mutans. The inhibition of ATPase activity may lead not only to energy starvation but also to decreased acid adaptation $[5,12]$.

Propolis is a recommended alternative to antibiotics, with antibacterial effects againsta wide range of bacteria including $E$. coli, S. aureus, S. epidermis, Enterococcus spp., and Bacillus cereus. Flavonoids were selected as the antibacterial agents in this study because they are a major phytochemical compound in propolis andare known to have antioxidant, anti-inflammatory, antifungal, antiviral, and antibacterial effects [13,14]. In addition, these antibacterial properties of flavonoids are stable for a long time. Previous studies have shown that the antibacterial effects of flavonoids persist for $10-15$ years provided they are kept at $10-11^{\circ} \mathrm{C}$ and not exposed to direct sunlight [13]. In addition, flavonoids are widely distributed in edible plants and beverages, they probably have minimal toxicity toward humans and may be safely used for children $[13,15]$.

Ethanol was used as a comparative antibacterial agent because it has been used as a basic ingredient in products such as mouthwashes, syrups, and pharmaceuticals. However, ethanol reported does exhibit toxicity and cause hypersensitivity or an allergic reaction and is linked to oral cancer [6,7]. In this study, we used $10 \%$ ethanol because it is the minimal ethanol concentration that can inhibit bacterial growth [16].

The time at which $S$. mutans was treated with propolis flavonoids were at $48 \mathrm{~h}$ of bacterial growth because this is the time at which the organism matures. Antibacterials will effectively kill bacteria when they are in the growth phase. In the maturation phase, bacterial growth begins to slow down because of the amount of nutrients becomes limited, resulting in increased resistance to antibacterials [17]. This phase is, therefore, a good point at which to determine the effectiveness of antibacterial agents.

According to previous studies, higher flavonoid concentrations have greater antibacterial activity; however, our findings did not support these. This may be because of several factors such as the mechanism of action of propolis flavonoids against intracellular S. mutans, the source or type of flavonoid fraction used, the bacterial strain used, interaction among medium components, incubation period, and the pipetting process.

A previous study suggested that flavonoids have multiple mechanisms by which they inhibit bacterial growth, for example, by releasing the energy of transduction to the cytoplasmic membrane and inhibiting bacterial motility [10]. Hydroxyl groups in flavonoids can inactivate organic components and disrupt nutrient transport in bacteria by binding to the protein components in the bacterial cell wall. The $\mathrm{F}_{0}$ component of ATPase is present in the cell membrane and flavonoids can thus inhibit ATPase accessibility as an $\mathrm{H}^{+}$proton pump. Inhibition of ATPase rotation causes a decrease in ATP production, resulting in impaired metabolism, intracellular $\mathrm{pH}$ disturbance, and decreased bacterial ability to survive. This is consistent with what is reported in the literature, in that through the molecular actions of their hydroxyl groups, flavonoids form a complex bond with bacterial wall proteins and inactivate enzymes and protein transport. Further, lipophilic flavonoids damage the bacterial membrane [18].
The source of flavonoids determines the antibacterial characteristics. In the present study, higher concentrations of flavonoids from propolis did not result in a proportional increase in antibacterial activity, probably because the fraction type extracted had different attributes. On the basis of the literature, the flavonoid fractions in propolis are flavonol (galangin), flavanone (pinocembrin), and flavone (apigenin). These three fractions have different chemical characteristics. A previous study showed that pinocembrin and galangin inhibit ATPase activity, although apigenin cannot or can but only slightly [19].

The difference in the mechanisms of action of each fraction produces different changes in ATPase activity. In the present study, we did not examine individual fractions. Therefore, we suggest that in-depth research is performed to identify the specific compound in propolis that inhibits ATPase activity. Based on the results of this study, propolis flavonoids of varying concentrations can be used as antibacterial alternatives. From the perspective of pharmacological concepts and economics, the lowest concentration would be ideal $(0.05 \%)$. However, in the case of propolis flavonoids with low toxicity, the highest concentration can be used $(0.5 \%)$.

\section{CONCLUSIONS}

Propolis flavonoids of concentrations $0.5 \%, 0.25 \%, 0.1 \%, 0.075 \%$, and $0.05 \%$ and $10 \%$ ethanol had similar effects in reducing S. mutans ATPase activity. We believe that $0.05 \%$ flavonoids from Trigona spp. Propolis can be used to reduce $S$. mutans ATPase activity. However, further in vitro and in vivo studies are necessary before a clinical study can be performed.

\section{ACKNOWLEDGMENT}

All authors have made substantial contributions to this study and/or manuscript and have reviewed the final paper before its submission. This study is funded by the Directorate of Research and Community Service, Universitas Indonesia, in 2017.

The publication is supported by Universitas Indonesia.

\section{REFERENCES}

1. Bagramian RA, Garcia-Godoy F, Volpe AR. The global increase in dental caries. A pending public health crisis. Am J Dent 2009;22:3-8.

2. Lundeen TF, Roberson TM. In: Studervant CM, Roberson TM, editors. Cariology: The Lesion, Etiology, Prevention and Control. $3^{\text {rd }}$ ed. St.Louis, Missouri: Mosby Inc.; 1995. p. 62.

3. Simon L. The role of Streptococcus mutans and oral ecology in the formation of dental caries. Lethbridge Undergrad Res J 2007;2:1-6.

4. Abachi S, Lee S, Rupasinghe HP. Molecular mechanisms of inhibition of Streptococcus species by phytochemicals. Molecules 2016;21. pii: E215.

5. Hasan S, Singh K, Danisuddin M, Verma PK, Khan AU. Inhibition of major virulence pathways of Streptococcus mutans by quercitrin and deoxynojirimycin: A synergistic approach of infection control. PLoS One 2014;9:e91736.

6. Lachenmeier DW. Safety evaluation of topical applications of ethanol on the skin and inside the oral cavity. J Occup Med Toxicol 2008;3:26.

7. Rodrigues F, Lehmann M, do Amaral VS, Reguly ML, de Andrade HH. Genotoxicity of three mouthwash products, cepacol, periogard, and plax, in the Drosophila wing-spot test. Environ Mol Mutagen 2007;48:644-9.

8. Pujirahayu N, Ritonga H, Uslinawaty Z. Properties and flavonoids content in propolis of some extraction method of raw propolis. Int $\mathrm{J}$ Pharm Pharm Sci 2014;6:338-40.

9. Kumar S, Pandey AK. Chemistry and biological activities of flavonoids: An overview. ScientificWorldJournal 2013;2013:162750.

10. Sharief N, Veni AS, Umamrao V. Quantification of phytochemical and antibacterial activity of fruit extract od Avicennia officialis. Asian J Pharm Clin Res 2014;7:10-3.

11. Utama A, Shimizu H, Hasebe F, Morita K, Igarashi A, Shoji I, et al. Role of the DExH motif of the Japanese encephalitis virus and hepatitis C virus NS3 proteins in the ATPase and RNA helicase activities. Virology 2000;273:316-24.

12. Lemos JA, Burne RA. A model of efficiency: Stress tolerance by 
Streptococcus mutans. Microbiology 2008;154:3247-55.

13. Bogdanov S. Propolis: Composition, health, medicine: A review. Bee Prod Sci 2016;6:1-42.

14. Jayshree N, Narayanan N, Sriram L. Antibacterial, antifungal and antimycrobacterial studies on some synthetic dimethoxy flavones. Asian J Pharm Clin Res 2012;5:2011-3.

15. Suseno D. Aktivitas Antibakteri Propolis Trigona spp. Pada Dua Konsentrasi Berbeda Terhadap Cairan Rumen Sapi, Biokimia, Program Studi Mipa, Institut Pertanian Bogor; 2009. p. 6-8.

16. Chatterjee I, Somerville GA, Heilmann C, Sahl HG, Maurer HH,
Herrmann M. Very low ethanol concentrations affect the viability and growth recovery in post-stationary-phase Staphylococcus aureus populations. Appl Environ Microbiol 2006;72:2627-36.

17. Bowden GH. Nutritional influences on biofilm development. Adv Dent Res 1997;11:81-99.

18. Wagh VD. Propolis: A wonder bees product and its pharmacological potentials. Adv Pharmacol Sci 2013;2013:308249.

19. Poór M, Veres B, Jakus PB, Antus C, Montskó G, Zrínyi Z, et al. Flavonoid diosmetin increases ATP levels in kidney cells and relieves ATP depleting effect of ochratoxin A. J Photochem Photobiol B 2014;132:1-9. 